\title{
COMPARATIVE ADVANTAGES OF CERVICAL INSEMINATION OVER NATURAL MATING ON PRODUCTION OF CROSSBRED LAMBS FOR EXPORT MARKET
}

\author{
Shanbel BESUFKAD ${ }^{\star 凶}$, Asfaw BISRAT, Chekol DEMIS, Ayele ABEBE, Aschalew ABEBE, Shenkute GOSHIME \\ and Tesfaye ZEWUDE
}

Debre Birhan Agricultural Research Center, P.O.Box 112, Debre Birhan, Ethiopia

Email: shanbel21@gmail.com

Supporting Information

\begin{abstract}
A study was conducted at Debre Birhan agricultural research center to evaluate the success of artificial insemination (Al) following oestrous synchronization in Washera ewes. A total of 32 ewes were selected from this center. All experimental animals were synchronized using single injection of 1 ml Enzaprost $\circledast$ intramuscularly at unknown stage of estrous cycle. Then ewes were divided into Dorper and Awassi fresh semen cervical insemination. Fixed time cervical insemination was performed in estrous ewes 48-51 hrs following $1 \mathrm{ml}$ Enzaprost ${ }^{\circledR}$ injection with $0.25 \mathrm{ml}$ fresh diluted Dorper and Awassi semen. Out of 32 ewes synchronized, 22 (68.8\%) of ewes exhibited overt sign of oestrous within $48 \mathrm{hrs}$ of hormone administration. Ewe's body condition score (BSC) wasn't found to be a significant factor determining oestrous response to hormone treatment. The overall pregnancy, lambing and fecundity rates for cervical insemination and natural mating were 63.64, 77.27, $121.43 \%$ and $57.46,61.57,107.14 \%$, respectively. There was no significant difference in pregnancy, lambing and fecundity rates among ewes mated with fresh semen cervical insemination and controlled ram mating $(\mathrm{P}<0.05)$. The pregnancy, lambing, and fecundity rates for Awassi and Dorper semen were 58.3, 75.0, 128.57\% and $70.0,80.0,114.29 \%$, respectively. No significance differences were observed in pregnancy, lambing and fecundity rates among the genotypes $(\mathrm{P}<0.05)$. The current work strongly indicated that artificial insemination following oestrous synchronization has a tremendous impact on terminal crossing, that allows us to import fewer exotic genotypes and producing large number of crossbreed lambs from imported breed with in few years.
\end{abstract}

Keywords: Artificial insemination, Commercial lamb production, Washera, Enzaprost

\section{INTRODUCTION}

Ethiopia is home for diverse small ruminant population, numbering 30.7 million sheep and 30.2 million goat head (CSA, 2017). They account for $40 \%$ of cash income earned by farm households, $19 \%$ of the total value of subsistence food derived from all livestock production, and $25 \%$ of total domestic meat consumption (Hirpa and Abebe, 2008). Despite the large numbers and the multiple roles small ruminant productivity in Ethiopia, is considered low as compared to productivity levels in developed livestock industries of the world (Gizaw et al., 2010). This low level of productivity could be attributed to several factors, chief among them is low genetic potential of the animals (Abebe et al., 2010; Kosgey et al., 2006; Tibbo et al., 2006).

Ethiopia meat exporters are not competent in the world market due to lack of supply from the traditional sheep husbandry that meets the export market standard. Since 2012 G.C., Debre Birhan agricultural research center (DBARC) has conducted research to evaluate combining ability of local ewes (Washera and Bonga sheep) with Awassi rams in growth and carcass traits. The experiment was designed to utilize the fast growth and larger carcass of exotic breed to satisfy the required export market standard. The study revealed that crossbred lambs that were finished at early age (on seven month of age) could satisfy the required export market standard (DBARC unpublished data).

However, reproduction data recorded in DBARC from 2013 to 2017 G.C., under terminal crossing of Washera ewes using Awassi rams showed that lambing was occurred in scatter manner (within 140 days of the commencement of lambing). This has great impact on effectiveness of terminal crossing and management of lambs to finish at early age. However, artificial insemination (Al) following oestrous synchronization could be a solution for achieving planned and concentrated lambing without significantly affecting pregnancy. In addition Al could be a solution to import fewer exotic genotypes and allows us to produce large number of crossbreed lambs from imported exotic sheep breed. Therefore, the objective of this study was to evaluate success of artificial insemination following oestrous synchronization in Washera sheep. 


\section{MATERIALS AND METHODS}

Experimental protocol was approved by the Amhara Agricultural Research center (ARARI), Bahir Dar, Ethiopia. This experiment was conducted on on-station, called Debre Birhan Agricultural research Center (DBARC), Debre Birhan, Ethiopia.

\section{Location of study area}

DBARC is located $120 \mathrm{~km}$ North-east of Addis Ababa at an altitude of 2,765 m.a.s.l. and at a latitude of $09^{\circ} 36^{\prime} 23^{\prime \prime} \mathrm{N}$ and longitude of $39^{\circ} 39^{\prime} 10^{\prime \prime} \mathrm{E}$. Debre Birhan is characterized by a bi-modal rainfall pattern, where the main rainy season is from June-September accounting for $75 \%$ of the total rainfall, an erratic unreliable short rainy season is February, March-April, May and a dry season October-January. Based on the meteorological data obtained from DBARC, the average annual rainfall is $923 \mathrm{~mm}$. The mean annual maximum temperature is $19.87^{\circ} \mathrm{C}$ occurs between March and June, while the mean annual minimum temperature is $6.59^{\circ} \mathrm{C}$ occurs between October and January.

\section{Experimental animals and their management}

A total of 32 Washera ewes were used for Al experiment. Ewe's age ranges from 4 to 6 years and that gave at least one birth, which their body condition score (BCS) are 2.5 and above and ewes not suckling were used in this trial. Whereas, in natural controlled mating system all ewes were sired by pure Awassi in a group of 26-30 ewes per ram and mating were lasted on average between 51 and 90 days. All experimental ewes were housed in the night and allowed to graze during the day on natural pasture daily for $6 \mathrm{hrs}$. In addition, the experimental animals were supplemented with $200 \mathrm{~g}$ head/day mixed commercial concentrate consists of $33 \%$ noug (Guizotia abyssinica) cake, $65.5 \%$ wheat bran, $1 \%$ limestone and $0.5 \%$ salt. The animals had free access to fresh water twice a day. As a routine flock health management practice of the research center the experimental animals were drenched against internal parasites (Rafoxanide at $1 \mathrm{ml} / 4 \mathrm{~kg}$ body weight, Chanelle pharmaceuticals manufacturing Ltd., Ireland and Tetraclozash-900® at 1 bolus/30kg body weight, Ashish life Science Pvt. Ltd., India) and were vaccinated against Ovine Pasteurellosis, Peste des Petitis Ruminants (PPR), Sheep and Goat Pox, Blackleg and Anthrax (National veterinary institute, Debrezeit, Ethiopia) in the different seasons of the year before the beginning of the experiment. Moreover, the experimental animals were sprayed against ectoparasites (Diazinol 60\% E.C at 1ml/1Lit. of clean water, Kafr EL Zayat pestisides and chemicals CO., Egypt) in July 2017.

\section{Oestrous synchronization}

All experimental ewes received single injection of $5 \mathrm{mg}$ of the PGF2 $\alpha$ analogue dinoprost (1 $\mathrm{ml}$ Enzaprost ${ }^{\circledR}$; CEVA laboratories, Libourne, France) intramuscularly at unknown stage of estrous cycle. Then ewes were subdivided into two groups randomly by blocking the animals for BCS and allocated to Awassi and Dorper fresh semen cervical insemination. Ewes were observed for oestrous at $4 \mathrm{hrs}$ intervals for a period of $48 \mathrm{hrs}$. Ewes were kept indoor the whole days during oestrous identification. Ewes at heat were identified using proven ram fitted with an apron. Standing to be mounted was the key sign used to determine oestrous response.

\section{Semen collection and artificial insemination}

Semen was collected from Awassi and Dorper rams trained to serve an artificial vagina (AV), after allowing the rams to mount in estrus ewes. Collected semen was immediately evaluated for volume, appearance (color and contamination), sperm cell concentration and mass motility. The volume of semen was measured with a calibrated collection glass and sperm cell concentration was evaluated using AccuRead IMV Technologies SA, 232 Spectrophotometer. Sperm mass motility was estimated subjectively by using phase contrast microscope (Scope Technology Scope Photo 3.0.12). The qualified semen to be used for Al was diluted with OviXcell extender (preservation medium for ovine semen, IMV Technologies, France). Fixed time cervical Al was performed in estrus ewes 48-51 hrs following $1 \mathrm{ml}$ Enzaprost ${ }^{\circledR}$ administration with $0.25 \mathrm{ml}$ diluted fresh semen (approximately $150 \times 106 \mathrm{sperm} / \mathrm{straw}$ and its mass motility score 3 and above) using a speculum equipped with a light source and an insemination gun, slowly releasing the semen into the first fold of the cervix.

\section{Statistical analysis}

The data were analyzed using Statistical Package for the Social Sciences (IBM SPSS version 20). Effects were considered to be significant when the level of probability was $5 \%$ or less.

Oestrous response, pregnancy, lambing, and fecundity rate were calculated by using the following formula:-

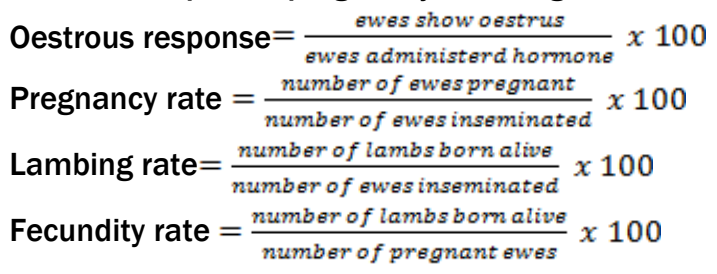




\section{RESULTS AND DISCUSSION}

\section{Oestrous response}

As indicated in Table 1, out of 32 ewes treated with single injection of PGF2 $\alpha$ analogue dinoprost (1 ml Enzaprost $\left.{ }^{\circledR}\right)$, $22(68.8 \%)$ ewes exhibited overt signs of oestrous within $48 \mathrm{hrs}$. of hormone administration. The current result revealed that oestrous could be effectively synchronized using single injection of PGF2 $\alpha$ analogue dinoprost (1 ml Enzaprost $\left.{ }^{8}\right)$ for achieving concentrated lambing and producing large number of crossbred lambs using Al within few years. Oestrous response attained in this trial was comparable to values (65\%) reported by Mekuriaw et al. (2015) in Menz sheep synchronized with single injection of PGF2 $\alpha$ ( $2 \mathrm{ml}$ Lutalyse ${ }^{\circledR}$ and $1 \mathrm{ml}$ Synchromate $\left.{ }^{\circledR}\right)$. Findings of the current study were however, higher than those obtained by Gizaw et al. (2016) who reported $57.5 \%$ oestrous response in Tigray highland sheep synchronized with single injection of PGF2 $\alpha\left(2 \mathrm{ml}\right.$ lutalyse $\left.{ }^{\circledR}\right)$ within $96 \mathrm{hrs}$. post hormone administration. However, it was lower than values reported by Gizaw et al. (2016) who recorded oestrous response of $80 \%$ in Washera sheep treated with single injections of PGF2 $\alpha\left(2 \mathrm{ml}\right.$ Lutylase $\left.{ }^{\circledR}\right)$. The differences in oestrous responses reported in different studies might be due to differences in breed, season and overall management conditions of the animals. In the current study, ewe's BSC wasn't found to be a significant factor determining oestrous response to hormone treatment. This may be due to ewes included in this experiment had a BCS of 2.5 and above. Ewes BCS of 2.5 and above are recommended BCS for achieving good reproduction in sheep. Santoralia et al. (2011) reviewed the factors affecting efficiency of synchronization indicated that high BCS has been associated with an increase of ovulation, with recommended BCS of 2.5-3.0 and a score of $<2$ resulting lowest pregnancy rates in sheep.

\section{Table 1 - Estrus response of Washera ewes to estrus synchronization protocol}

\begin{tabular}{lcccc} 
Parameter & $\boldsymbol{n}$ & Oestrous response (\%) & X2 & P value \\
\hline Body condition & & & 1.663 & 0.265 \\
$\quad$ Between 2.5 and 3.0 & 17 & 58.8 & & \\
3.5 and above & 15 & 80.0 & \\
Overall & 32 & 68.8 & \\
\hline
\end{tabular}

\section{Pregnancy, lambing and fecundity rates}

To evaluate the comparative advantages of cervical insemination following oestrous synchronization over natural mating on production of crossbreed lambs, five years reproduction data $(n=268)$ recorded under controlled natural mating at DBARC were used as a comparison. The overall pregnancy, lambing and fecundity rates recorded in the natural mating were $57.46,61.57$ and $107.14 \%$ respectively, while the overall pregnancy, lambing and fecundity rates recorded following oestrous synchronization and Al were $63.64,77.27$ and $121.43 \%$, respectively. There was no significant difference in pregnancy, lambing and fecundity rates among ewes mated with fresh semen cervical insemination and controlled ram mating $(P<0.05)$. Moreover pregnancy, lambing and fecundity rates for Awassi $\times$ Washera and Dorper $\times$ Washera were $58.3,75.0,128.57 \%$ and $70.0,80.0,114.29 \%$, respectively. No significance differences were observed in pregnancy, lambing and fecundity rates among the genotypes $(P<0.05)$.

The current pregnancy, lambing and fecundity rate falls in an acceptable range. According to Allaoui et al. (2014) in sheep, fertility rates ranges from 60 and $100 \%$ qualified as acceptable performance, in this regard the present study revealed that implementation of fresh semen cervical insemination in Awassi $\times$ Washera terminal crossing could be a solution for achieving concentrated lambing and also allows us to producing large number of crossbreed lambs from imported breed. The overall pregnancy and lambing rates achieved in the current study under fresh semen cervical insemination was comparable to values reported by Allaoui et al. (2014); Kumar et al. (2015); Pervag et al. (2010); Najafi et al. (2014). However, it was lower than values obtained by Mekuriaw et al. (2005) who reported pregnancy rates of 70.6 and $\mathbf{7 0 . 4 \%}$ in Dorper sheep synchronized with MAP and FGA sponges respectively. Similarly Fornazari et al. (2018) reported pregnancy rates of $76.5 \%$ in Assaf sheep synchronized with progestagen sponges. However, the current result was higher than value obtained by Olivera-muzante et al. (2011) who reported a pregnancy rate of $51 \%$ synchronized with two doses of PGF2 $\alpha 7$ days apart and inseminated cervically with fresh semen. Pregnancy rate under fresh semen cervical insemination was not significantly influenced by BCS of ewes on the other hand, ewes BCS was found to be a significant factor determining lambing and fecundity rates (Table 2). Study in Suffolk ewes showed that BCS of ewes was not significantly affected pregnancy rate (Fukui et al., 2010). However, it is contrary to the findings of Gizaw et al. (2016) who reported the significant implication of BCS on fertility rates of ewes. Under natural mating experiment, effect of ewe's BCS on pregnancy, lambing and fecundity rates were not considered because in case of natural mating ewes were allocated to rams based on their live body weight without scoring their BCS. However, as routine flock management of the research center ewes that had poor BCS were not included in the mating group. 
Table 2 - Pregnancy, lambing and fecundity rates (\%) in Washera sheep

\begin{tabular}{|c|c|c|c|c|}
\hline Factors & $\mathrm{n}$ & Pregnancy rates & Lambing rates & Fecundity rates \\
\hline P-value & & ns & ns & ns \\
\hline Natural mating & 268 & 57.46 & 61.57 & 107.14 \\
\hline Artificial insemination & 22 & 63.64 & 77.27 & 121.43 \\
\hline Genotype & & ns & ns & ns \\
\hline Awassi $\times$ Washera & 12 & 58.3 & 75.0 & 128.57 \\
\hline Dorper $\times$ Washera & 10 & 70.0 & 80.0 & 114.29 \\
\hline Body condition score & & ns & * & * \\
\hline Between 2.5 and 3.0 & 10 & 70.0 & $110.0^{b}$ & $157.14^{b}$ \\
\hline 3.5 and above & 12 & 58.3 & $50.0^{a}$ & $85.71^{\mathrm{a}}$ \\
\hline
\end{tabular}

\section{CONCLUSION}

The current work strongly indicated that oestrous could be effectively synchronized using single injection of $1 \mathrm{ml}$ Enzaprost $\left.{ }^{\circledR}\right)$ for achieving concentrated lambing in Washera sheep. This study revealed that no statistical significant difference was observed in pregnancy, lambing and fecundity rates among ewes mated with fresh semen cervical insemination and controlled ram mating. Al could be thought possible as a strategy in production of crossbred lambs for export market. Fresh semen AI has a tremendous impact on terminal crossing, allows us to import fewer exotic genotypes and producing large number of crossbreed lambs from imported breed within few years.

\section{Recommendations}

For successful oestrous synchronization application ewes that have a body condition score of 2.5 or above should be considered. In addition to the use of fresh semen Al, the success rate of Al with chiled and frozen ram semen in Washera sheep needs to be further investigated.

\section{DECLARATIONS}

\section{Authors' contribution}

Shanbel $B$ contributed to the research design, analysis, interpretation of the data and writing the manuscript. Chekol D contributed to prostaglandin administration. Asfaw B, Ayele A, Aschalew A, Shenkute G and Tesfaye $Z$ contributed to field implementation of the research work.

\section{Acknowledgements}

I am indebted to express my deepest respect and heartfelt thanks to the staff of livestock department of DBARC for their ultimate support to facilitate research animals and laboratory equipments. I am very grateful to my partner Mekibeb Worku and Deribew Bekele for their unreserved support during research works.

\section{Conflict of interest}

None of the authors have any conflict of interest to declare.

\section{REFERENCES}

Abebe G, Kannan G and Goetsch AL (2010). Effects of small ruminant species and origin (highland and lowland) and length of rest and feeding period on harvest measurements in Ethiopia. African Journal of Agricultural Research, 5.(9): 834-847. https://academicjournals.org/journal/AJAR/article-stat/BED280D28053

Allaoui A, Tlidjane M, Safsaf B and Laghrour W (2014). Comparative Study between Ovine Artificial Insemination and Free Mating in Ouled Djellal Breed. Apcbee Procedia, 8 December, 2014, Pp. 254-259. https://www.sciencedirect.com/science/article/pii/S221267081400116X

CSA (Central Statistical Agency) (2017). Agricultural sample survey 2016/17. Report on livestock and livestock characteristics (private peasant holdings). Vol. II, Addis Ababa, Ethiopia. Pp. 13.

Fornazari RR, Mateus Ó, Correia TM, Quintas H, Maurício R, Conradi A and Valentim R (2018). Estrus synchronization and artificial insemination with fresh and chilled semen in Assaf ewes. Agricultural Sciences, 9 (1): 8-22. https://bibliotecadigital.ipb.pt/handle/10198/17339

Fukui Y, Kohno H, Okabe K, Katsuki S, Yoshizawa M, Togari T and Watanabe H (2010). Factors affecting the fertility of ewes after intrauterine insemination with frozen-thawed semen during the non-breeding season. The Journal of Reproduction and Development,56 (4): 460-466. https://www.jstage.jst.go.jp/article/ird/advpub/0/advpub 10-015T/ article/-char/ja/

Gizaw S, Tegegne A, Gebremedhin B and Hoekstra D (2010). Sheep and goat production and marketing systems in Ethiopia: Characteristics and strategies for improvement. IPMS (Improving Productivity and Market Success) of Ethiopian Farmers Project Working Paper 23. ILRI (International Livestock Research Institute), Nairobi, Kenya. Pp. 58. https://cgspace.cgiar.org/bitstream/handle/10568/2238/IPMS Working_?sequence=1

Gizaw S, Tesfay T, Mekasha Y, Mekuriaw Z, Gugsa T, Ebro A, Gebremedhin B, Hoekstra D and Tegegne A (2016). Hormonal oestrus synchronization in four sheep breeds in Ethiopia: impacts on genetic improvement and flock productivity. LIVES Working 
Paper 25. Nairobi, Kenya: International Livestock Research Institute (ILRI). https://cgspace.cgiar.org/bitstream/handle/10568/78637/LIVES_wp_25.pdf?sequence=1

Hirpa A and Abebe G (2008). Economic Significance of Sheep and Goats. In In Yami A., Merkel R.C. (eds), Sheep and goat production handbook for Ethiopia. Ethiopian Sheep and Goat Productivity Improvement Program (ESGPIP). Pp. 1-4. http://agris.fao.org/agris-search/search.do?recordID=ET2008000088

Kosgey IS, Baker RL, Udo HM and Van Arendonk JA (2006). Successes and failures of small ruminant breeding programmes in the $\begin{array}{lllll}\text { tropics: a } & \text { Ruminant } & \text { Research, 61(1), } & 13-28 .\end{array}$ https://www.sciencedirect.com/science/article/abs/pii/S0921448805000258

Kumar KP (2015). Evaluation of estrus synchronization with different doses of Prostaglandin $\mathrm{f} 2 \alpha$ in Nellore Jodipi ewes. Doctoral dissertation, Sri Venkateswara Veterinary University, TirupaTI-517 502, AP. https://krishikosh.egranth.ac.in/handle/1/5810012934

Mekuriaw Z, Greyling JP, Schwalbach LM, Muller T and Erasmus JA (2005). Effect of progestagen and PMSG on oestrous synchronization and fertility in Dorper ewes during the transition period. Small Ruminant Research56 (1-3): 47-53. https://www.sciencedirect.com/science/article/abs/pii/S0921448804000057

Mekuriaw Z, Assefa H, Tegegne A and Muluneh D (2015). Estrus response and fertility of Menz and crossbred ewes to single prostaglandin injection protocol. Tropical animal health and production, 48 (1): 53-57. https://link.springer.com/article/10.1007/s11250-015-0919-z

Najafi G, Cedden F, Kohram H and Akbari Sharif A (2014). The effects of using artificial insemination techniques on reproductive performance in Ghezel sheep. International Journal of Advanced Biological and Biomedical Research 2 (12): 2898-2904. https://pdfs.semanticscholar.org/d3b1/305feb2bd6c05875251eb6d589e72f3329fe.pdf

Olivera-Muzante J, Fierro S, López V and Gil J (2011). Comparison of prostaglandin-and progesterone-based protocols for timed

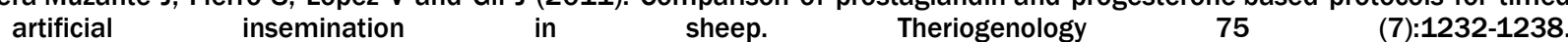
https://www.sciencedirect.com/science/article/abs/pii/S0093691X10006291

Pervage S, Hassan M, Ershaduzzaman M and Khandoker M (2010). Preservation of liquid semen and Artificial Insemination in native sheep. Journal of the Bangladesh Agricultural University, $7(2)$. https://www.banglajol.info/index.php/JBAU/article/view/4739

Santolaria P, Palacin I and Yániz J (2011). Management Factors Affecting Fertility in Sheepln: Artificial Insemination in farm animals. http://www.intechopen.com/books/artificial-insemination-in-farm-animals/management-factors-affectingfertilityin-sheep

Tibbo M (2006). Productivity and health of indigenous sheep breeds and crossbreds in central Ethiopian Highlands (Doctoral swedis University of https://cgspace.cgiar.org/bitstream/handle/10568/4074/produc_health.pdf?...1

Agricultural Sciences) 